\title{
Editorial
}

\section{Inclusion: Focus on social behavior}

\author{
David N. Ellis * \\ University of South Alabama, Mobile, Alabama, USA
}

The goals of education are to prepare students for adult life, specifically, to teach skills for productivity and selfsufficiency and, more broadly, to give them experiences that enhance their quality of life. These goals also apply to students with special needs. In the United States, as policy for students with developmental disabilities moves to an integrated or inclusive orientation, service agencies have begun to move from centralized to distributed service delivery systems.

Central to successful participation in inclusive school and community environments are language development, communication and social skills. If the goal of education is to prepare a student for the best possible adult outcomes, then appropriate school programs for students with special needs must focus on these foundational skills and abilities. In the United States, students with special needs are guaranteed a free, appropriate, public education (FAPE) through an individualized education plan (IEP).

Recent legislation and court cases have moved the United States toward policies that support integrating students with special needs into general education settings. In advocating for individual students it is necessary to examine the appropriateness of the integrated settings to determine if the curriculum, instructional practices, and resources are adequate to provide an appropriate education. Including the preferences of the child and parents in determining appropriateness can contribute to program success. Although students may be physically integrated with their classmates, school communities must be inclusive and supportive of the educational needs of students with disabilities, including needs in language, communication, and social skills.

Passage of the Education of Handicapped Children Act in 1975, which was the first comprehensive special education law, ensured an expectation that services be delivered in the least restrictive environment (LRE). LRE is sometimes used interchangeably with the concept of inclusion. Inclusion assumes that the student is in a general education placement, and that his or her removal from that placement, for whatever period of time, must be justified based upon educational need. Thus, it is the assumptions related to LRE that define the inclusion orientation to service delivery.

Communicative and social behaviors are integrally tied to the development of language and cognition as well as being determined by the interactions of internal systems and environmental conditions [1]. Hence, for persons with developmental disabilities, these behaviors are arguably the most important determinant of successful independent living. Because of the dynamic nature of development coupled with assumptions of participation in inclusive social environments, an early focus on the development of social skills and progressive transition for individuals based on skill acquisition and developmental status is crucial.

In the United States the approach to diagnosis and service for individuals with developmental disabilities has evolved from medical or deficit models to definitions focused on the relationship between personal attributes and life environments [2]. This evolution began in the middle of the 20th century as Dexter [3] and, later, Mercer [4] proposed that mental retardation was a construct based on social roles. These roles are defined by behavioral expectations and concomitant natural supports. Therefore success and quality of life are tied to the fulfillment of expectations for perceived roles in social systems.

B. F. Skinner [5] believed that our complex language systems were not so much the product of our capacity for thought and reason but of the evolution of complex social environments. We must, then, include in our analysis

\footnotetext{
* Korespondenční autor: David N. Ellis, Professor of Special Education, University of South Alabama, Mobile, Alabama, USA; e-mail: dellis@southalabama.edu http://dx.doi.org/10.1016/j.kontakt.2016.08.005
} 
and instructional design elements of the social and environmental ecology in order to develop a general social/ communicative repertoire [6]. Within the last several decades our approach to defining and serving persons with developmental disabilities has shifted so that we now view an individual within a variety of social ecologies that change with time and development [2].

In order for professionals to improve the social and communicative behaviors of persons with developmental disabilities, interventions must be individualized, functional and ecologically valid. Before now, typical patterns of support and education for persons with developmental disabilities have tended to be static and situational. We know that a wide range of program options is necessary to address the breadth of individual needs of students with developmental disabilities. Shortterm, intensive segregated arrangements may prove most effective and appropriate when they are an intermediate means to a specific end.

A service orientation that is aware of and values personal potential must acknowledge change attributable to maturation and achievement and be capable of promoting transitional functions and roles. Thus, rather than training people to fulfill a current defined role and supporting them in it, service providers must systematically develop roles that match each individual across time.

Skinner looked at verbal behavior as "behavior reinforced by the mediation of other persons" [5, p. 2]. To be ecologically valid and promote generalized functionality, communication training should occur in all environments in which the individual participates, anticipate potential future environments, and address problem solving and social interaction. Language, communication, and social skills training programs may also need to target assistive or augmentative forms along with social function. For these systems to be functional they must first be practical and effective in current and future social environments.

Luria's [7] three functions of language: communication, thinking, and self-regulation have direct implications for independent functioning in social environments. Many children with developmental disabilities experience intellectual challenges and concomitant issues with selfmanagement. Programs designed to promote language development and communication skills can impact thinking or cognition, and self-regulation. Miller and Yoder [8] caution that interventions based solely on imitation, modeling, and differential reinforcement will only lead to the learning of surface structures. Instead they argue that attention should be paid to the individual's representational abilities and conceptual development because these skills are central to developing functional language. The content, instructional sequences and strategies should all be chosen based on levels of cognitive and linguistic development.

Communication, thinking, and self-regulation, are inter-related in the developmental functions of language. Schools must recognize the ongoing importance of integrating these three functions of language into the goals of IEPs to promote positive quality of life outcomes in school and community environments. In the United States language development there is typically an emphasis on teaching younger children, while social skills and self- determination training programs are implemented for adolescents in anticipation of their transition to adult life. Additionally, communication training is likely to be emphasized for students with autism or as part of behavioral interventions. Obviously these program strategies rely on disability categories and not individual needs or comprehensive curricular design.

Educational services have the responsibility of preparing children who have disabilities to be part of our families and communities. Human rights issues for people with disabilities include increased risk of discrimination in education [9]. Changes in public perception and expectations cannot be legislated and will be slow to evolve. Acknowledging the human rights of those with developmental disabilities through policies of inclusion in education and community is a necessary first step. To realize these goals future research should focus on effective strategies for early intervention, systems of care to treat preventable causes of poor health in children and adults with disabilities, improvement of support for families and training of health care workers [10].

\section{REFERENCES}

[1] Chomsky N. Rules and representations. New York: Columbia University Press; 1980.

[2] Odom SL, Horner RH, Snell ME, Blacher J. The construct of developmental disabilities. In: Odom SL, Horner RH, Snell ME, Blacher J. (eds). Handbook of developmental disabilities. New York: Guilford; 2007, pp. 3-14.

[3] Dexter L. A social theory of mental deficiency. American Journal of Mental Deficiency 1958;62(5):920-8.

[4] Mercer JR. Sociological perspectives on mild mental retardation. In: Haywood H.C. (ed.). Social cultural aspects of mental retardation. New York: AppletonCentury-Crofts; 1970.

[5] Skinner BF. Verbal behavior. New York: AppletonCentury-Crofts; 1957.

[6] Odom SL, Haring TG. Contextualism and applied behavior analysis. In: Gardner R, Sainato DM, Cooper JO, Heron TE., Heward WL, Eshleman J. et al. (eds). Behavior analysis in education. Pacific Grove, CA: Brooks/Cole; 1994.

[7] Luria AR. The role of speech in the formation of temporary connections and in the regulation of the behavior of child-oligophrenics. In: Luria AR. (ed.) The mentally retarded child. Oxford, England: Pergamon; 1958.

[8] Miller JF, Yoder DE. An ontogenetic language teaching strategy for retarded children. In: Schiefelbusch RL, Lloyd LL. (Eds). Language perspectives - Acquisition, retardation, and intervention. Baltimore: University Park Press; 1974, pp. 505-28.

[9] World Report on Disability 2011. Geneva: WHO. [online] [cit. 2016-07-10]. Available from: http://www. who.int/disabilities/world_report/2011/report.pdf

[10] Tomlinson M, Yasamy MT, Emerson E, Officer A, Richler D, Saxena S. Setting global research priorities for developmental disabilities, including intellectual disabilities and autism. Journal of Intellectual Disability Research 2014;58(12):1121-30. 